\title{
Problematika Hukum Implementasi Putusan Final dan Mengikat Mahkamah Konstitusi Perspektif Negara Hukum
}

\author{
Mohammad Agus Maulidi \\ Fakultas Hukum Universitas Islam Indonesia \\ Jln. Tamansiswa No. 158 Yogyakarta \\ maulidi.fhuii@gmail.com
}

Received: 18 Januari 2018; Accepted: 14 Februari 2018; Published: 5 Juni 2018

DOI: 10.20885/iustum.vol24.iss4.art2

\begin{abstract}
Seen from normative legal aspect, a decision of the Constitutional Court is final and binding since mentioned in a plenary session open to the public. This means that, by the time it has a permanent legal force, there is no need for other legal actions in the forms of appeal and cassation, including any efforts to correct it; the decision is the first and final resort. As a consequence, a decision of the Constitutional Court may not be disallowed or even ignored. The problem formulation in this study is, first, what are the meaning and effects of final and binding decisions of the Constitutional Court? Second, why are the decisions of the Constitutional Court not able to be implemented consistently? This was a normative legal study with philosophical and statute approaches. The findings revealed that first, final decisions mean that the decisions of the Constitutional Court are the first and the last resort so that no further legal actions can be taken against the decisions, and this way these decisions have permanent and binding legal force to be implemented. Second, there are several factors why the final and binding decisions of the Constitutional Court are not implemented consistently: (i) the Constitutional Court only serves as a negative legislature, (ii) there are no special enforcement agencies, (iii) there is no grace period for the implementation of decisions, (iv) there are no consequences of ignoring of the decisions of the Constitutional Court.
\end{abstract}

Keywords: Decisions of constitutional court; final; binding

\section{Abstrak}

Secara normatif-yuridis, putusan MK bersifat final dan mengikat sejak diucapkan dalam sidang pleno yang terbuka untuk umum. Artinya, sejak memiliki kekuatan hukum tetap, tidak ada upaya hukum lanjutan berupa banding dan kasasi, termasuk juga upaya untuk mengoreksi, putusannya merupakan tingkat pertama sekaligus terakhir. Konsekuensinya, putusan MK tidak boleh dianulir atau bahkan diabaikan. Rumusan masalah yang diangkat dalam penelitian ini adalah, pertama, apa makna dan akibat hukum putusan final dan mengikat Mahkamah Konstitusi? Kedua, mengapa putusan MK tidak dapat diimplementasikan secara konsekuen? Metode yang digunakan dalam penelitian ini yaitu yuridis-normatif dengan pendekatan filosofis dan perundang-undangan. Hasil penelitian ini menyimpulkan pertama, putusan final berarti bahwa putusan MK merupakan upaya yang pertama (the first resort) sekaligus upaya terakhir (the last resort) yang mempunyai konsekuensi tidak ada upaya hukum lebih lanjut yang dapat ditempuh terhadap putusan, dan karenanya secara langsung mempunyai kekuatan hukum tetap dan mengikat untuk dilaksanakan. Kedua, terdapat beberapa faktor tidak diimplementasikannya putusan final dan mengikat Mahkamah Konstitusi secara konsekuen (i) kedudukannya Mahkamah Konstitusi hanya sebagai negative legislature, (ii) tidak adanya special enforcement agencies, (iii) tidak adanya tenggang waktu untuk mengimplementasikan putusan, (iv) tidak adanya konsekuensi atas pengabaian terhadap putusan Mahkamah Konstitusi.

Kata-kata Kunci : Putusan mahkamah konstitusi; final; dan mengikat 


\section{Pendahuluan}

Mahkamah Konstitusi (MK) sebagai anak kandung reformasi telah memberikan harapan baru untuk menjawab kompleksitas perkembangan ketatanegaraan Indonesia. ${ }^{1}$ Keberadaannya merupakan usaha melembagakan supremasi konstitusi. ${ }^{2}$ Hingga saat ini, MK menjadi satu-satunya lembaga negara yang mempunyai kewenangan konstitusional untuk menafsirkan dan mengawal kemurnian konstitusi. Karena itu, MK disebut sebagai the sole interpreter of constitution dan the guardian of the constitution. ${ }^{3}$

Layaknya institusi peradilan pada umumnya, MK juga mengeluarkan produk hukum berupa putusan. Perbedaan yang sangat mendasar antara putusan yang dikeluarkan oleh MK dengan institusi peradilan lainnya yaitu mengenai upaya hukum lanjutan atas putusannya. Jika putusan yang dikeluarkan oleh institusi peradilan lainnya (Mahkamah Agung dan peradilan di bawahnya) dapat dilakukan upaya hukum lanjutan, baik berupa banding, kasasi, maupun peninjauan kembali, putusan MK tidak mengadopsi mekanisme tersebut. Dikatakan di dalam konstitusi bahwa MK merupakan peradilan tingkat pertama dan terakhir yang putusannya bersifat final. ${ }^{4}$ Dipertegas kembali di dalam Pasal 10 Undang-Undang Nomor 8 Tahun 2011 tentang Perubahan Atas Undang-Undang Nomor 24 Tahun 2003 tentang Mahkamah Konstitusi bahwa makna sifat final putusan MK juga mencakup di dalamnya kekuatan mengikat. Artinya, putusan MK langsung memperoleh kekuatan hukum tetap sejak diucapkan dan tidak ada upaya hukum yang dapat ditempuh.

Permasalahan kemudian muncul ketika putusan MK membutuhkan tindak lanjut untuk merealisasikannya, dan menjadikan institusi lain untuk menindaklanjuti putusan tersebut. Faktanya, kekuatan final dan mengikat putusan MK tidak dapat diimplementasikan secara konkret (non-excutiable) dan hanya mengambang (floating execution). Penelitian ini akan mengambil contoh putusan

\footnotetext{
${ }^{1}$ Tim Penyusun Hukum Acara Mahkamah Konstitusi, Hukum Acara Mabkamah Konstitusi, Cetakan Pertama, Sekretariat Jenderal dan Kepaniteraan Mahkamah Konstitusi, Jakarta, 2010, hlm. 1

2 Moh. Mahfud MD, "Peran Mahkamah Konstitusi dalam Pengembangan Hukum dan Demokrasi di Indonesia" dalam Mariyadi Faqih, "Nilai-Nilai Filosofi Putusan Mahkamah Konstitusi yang Final dan Mengikat", Jurnal Konstitusi, Volume 7, Nomor 3, Juni 2010, hlm. 97

3 Jimly Asshiddiqie, Perkembangan \& Konsolidasi Lembaga Negara Pasca Reformasi, Edisi Kedua, Cetakan Kedua, Sinar Grafika, Jakarta, 2012, hlm. 132

${ }_{4}$ Pasal 24C Undang-Undang Dasar Negara Republik Indonesia Tahun 1945.
} 
MK yang menjadikan cabang kekuasaan negara baik eksekutif, legislatif, maupun cabang kekuasaan yudikatif yaitu Mahkamah Agung (MA) sebagai addressat putusan MK, namun justru diabaikan atau tidak ditindaklanjuti.

Putusan MK yang tidak dilaksanakan oleh MA misalnya adalah Putusan Nomor 34/PUU-XI/2013 yang membatalkan Pasal 268 ayat (3) KUHAP. Akibat hukum dari putusan tersebut yaitu bahwa Peninjauan Kembali (PK) dapat diajukan oleh terpidana atau ahli warisnya lebih dari sekali selama masih memenuhi syarat-syarat yang ditentukan dalam Pasal 268 ayat (2) KUHAP. Putusan MK ini kemudian dianulir oleh MA melalui Surat Edaran Mahkamah Agung (SEMA) Nomor 07 Tahun 2014 tentang Pengajuan Permohonan Peninjauan Kembali Dalam Perkara Pidana. Substansi dari SEMA tersebut adalah untuk menegaskan bahwa PK hanya dapat dilakukan 1 (satu) kali.

Putusan MK yang tidak dilaksanakan oleh cabang kekuasaan eksekutif secara konsekuen yaitu Putusan Nomor 5/PUU-X/2012 tentang pengujian Pasal 50 ayat (3) Undang-Undang Nomor 20 Tahun 2003 tentang Sistem Pendidikan Nasional. Persoalan implementasi putusan MK pada konteks ini yaitu pemerintah melalui Kementerian Pendidikan dan Kebudayaan masih menempuh kebijakan masa transisi untuk menghapus kebijakan Sekolah Bertaraf Internasional (SBI) dan/atau Rintisan Sekolah Bertaraf Internasional (RSBI). ${ }^{5}$ Padahal hakikatnya, Putusan MK tidak mengenal masa transisi untuk dilaksanakan, namun mempunyai kekuatan hukum mengikat sejak diucapkan, yang artinya sejak saat itu pula harus dipatuhi dan diimplementasikan.

Putusan yang tidak dilaksanakan oleh cabang kekuasaan legislatif misalnya adalah Putusan Nomor 011/PUU-III/2005 yang menyatakan bahwa penjelasan Pasal 49 ayat (1) Undang-Undang Sistem Pendidikan Nasional (UU Sisdiknas) tidak mempunyai kekuatan hukum mengikat. Pada putusan tersebut MK berpendapat bahwa pada hakikatnya pelaksanaan konstitusi tidak boleh ditundatunda, termasuk ketentuan anggaran minimal 20 persen dari APBN untuk pendidikan telah dinyatakan secara expres verbis, sehingga tidak boleh direduksi

\footnotetext{
${ }^{5}$ Fajar Laksono, dkk., "Implementasi Putusan Mahkamah Konstitusi Nomor 92/PUU-X/2012 Terkait Kewenangan Dewan Perwakilan Daerah dalam Pembentukan Undang-Undang” Jurnal Konstitusi Volume 12, Nomor 3, September 2015, hlm. 5
} 
oleh peraturan perundang-undangan di bawahnya. Namun, pada undang-undang yang lain yaitu Undang-Undang tentang APBN Tahun 2005 panitia anggaran DPR hanya mengalokasikan anggaran sebesar 36 Triliun atau setara dengan 8,1 persen dari total anggaran yang ada. ${ }^{6}$

Beberapa contoh di atas menunjukkan bahwa putusan MK mempunyai ketegasan hanya pada tataran normatif saja. Putusan MK hanya tampak populis serta progresif di permukaan, namun justru tidak jarang putusannya 'gagal' melimpahkan keadilan dan kepastian hukum karena berhenti pada putusan normatif yang tidak sepenuhnya diimplementasikan secara konsekuen oleh lembaga yang terkena adressat putusan. Hal ini terutama berkaitan erat dengan putusan yang berada dalam ranah judicial review atau pengujian undang-undang. Sebaliknya, implementasi putusan MK sangat tergantung pada cabang kekuasaan lain baik legislatif, eksekutif maupun cabang kekuasaan kehakiman berupa MA.

Keadaan tersebut tentu telah sangat jelas menunjukkan bahwa keberadaan MK hingga saat ini belum mempunyai daya tawar yang kuat sebagai satu-satunya lembaga tinggi negara yang mempunyai otoritas mengawal sekaligus menafsirkan konstitusi. Terlebih keberadaan MK memang tidak mempunyai ranah dan wewenang untuk ikut andil dalam proses implementasi putusannya sendiri. Tidak salah apabila dikatakan bahwa MK merupakan cabang kekuasaan dalam struktur ketatanegaraan yang paling lemah di antara cabang-cabang kekuasaan negara lainnya (the least dangerous power, with no purse nor sword). ${ }^{7}$

Apabila keadaan tersebut terus dibiarkan, perkembangan dan kedudukan MK dalam struktur ketatanegaraan di Indonesia hanya akan menjadi formalitas belaka, di samping juga tingkat kepercayaan publik terhadap MK akan menurun. Pada gilirannya, MK kehilangan marwah sebagai lembaga penafsir dan pengawal konstitusi sebagaimana original intent dibentuknya MK. Konsekuensi logis dari hal tersebut, MK akan ditinggalkan oleh para pencari keadilan.

\footnotetext{
6 Anonim, “APBN 2006, Pemerintah dan DPR Abaikan Putusan MK” dalam http:/ /www.hukumonline.com/berita/baca/hol13876/apbn-2006-pemerintah-dan-dpr-abaikan-putusan-mk, diakses pada tanggal 05 Mei 2017

${ }^{7}$ Alexander Hamilton, “The Federalist Paper" Dalam Maruarar Siahaan, Undang-Undang Dasar 1945 Konstitusi Yang Hidup, Sekretariat Jenderal dan Kepaniteraan Mahkamah Konstitusi, Jakarta, 2008, hlm. 607
} 
Pada aspek kepastian hukum, persoalan sebagaimana dijelaskan di atas tentu menjadi permasalahan yang sangat fundamental. MK sebagai pengawal konstitusi dan bentuk dari pelembagaan menuju supremasi konstitusi tentu akan jauh dari cita-citanya. Dapat dikatakan bahwa diimplementasikannya putusan MK secara konsekuen merupakan indikator utama tegaknya supremasi konstitusi. Pada ruang lingkup yang lebih luas, hal tersebut merupakan cerminan atas tegaknya negara hukum. Putusan MK hanya menjadi macan kertas, tidak implementatif dan dapat mencederai pemahkotaan supremasi hukum. ${ }^{8}$

\section{Rumusan Masalah}

Berdasarkan uraian permasalahan di atas, maka penelitian ini akan mengangkat 2 rumusan masalah yaitu: pertama, apakah makna dan akibat hukum putusan final dan mengikat Mahkamah Konstitusi? Kedua, mengapa putusan final dan mengikat Mahkamah Konstitusi tidak implementatif?

\section{Tujuan Penelitian}

Sebagai tindak lanjut dari rumusan masalah yang telah ditetapkan di atas, maka tujuan dilakukannya penelitian ini adalah: Pertama, mengetahui dan menganalisismakna dan akibat hukum putusan final dan mengikat Mahkamah Konstitusi. Kedua, mengetahui dan menganalisis alasan dan faktor putusan final dan mengikat Mahkamah Konstitusi tidak implementatif

\section{Metode Penelitian}

Penelitian ini merupakan jenis penelitian hukum normatif, yaitu dengan meneliti bahan kepustakaan. Penelitian ini menggunakan pendekatan filosofis karena objek penelitian mengkaji makna dan akibat hukum putusan final dan mengikat Mahkamah Konstitusi. Di samping itu, juga digunakan pendekatan perundang-undangan untuk mengetahui alasan putusan MK tidak implementatif.

8 Ahmad Syahrizal, "Problem Implementasi Putusan MK" Jurnal Konstitusi, Volume 4, Nomor 1, Maret 2007, hlm. 112 


\section{Hasil Penelitian dan Pembahasan}

\section{Makna Final dan Mengikat Putusan Mahkamah Konstitusi}

Mengetahui makna dan sifat putusan MK, juga penting untuk menganalisis sejarah munculnya klausul pengaturan tersebut, guna mengetahui original intent para perumusnya. Hal ini kiranya sangat sejalan dengan penjelasan UUD 1945 sebelum perubahan yang menyatakan bahwa UUD di negara manapun tidak akan dapat dimengerti secara tepat apabila hanya dibaca teksnya begitu saja. Untuk dapat dimengerti secara sungguh-sungguh maksud ketentuan UUD dari suatu negara, perlu dipelajari bagaimana proses terjadinya teks tersebut, harus dipahami keterangan-keterangannya, dan juga harus diketahui dalam suasana apa teks tersebut dirumuskan. Dengan demikian, akan diketahui maksud ketentuan undang-undang, bahkan peristiwa atau pikiran apa yang mendasari dan melingkupinya. ${ }^{9}$ Berkaitan dengan ini pula, menurut Fajar Laksono Soeroso, pendekatan original intent sebagai bagian dari aliran originalism menjadi sangat relevan sebagai pijakan teoretis. Terdapat 2 (dua) teori besar dalam aliran ini, yaitu original intent theory, yang mengatakan bahwa interpretasi dari sebuah konstitusi tertulis adalah sesuai dengan apa yang dimaksud oleh orang-orang yang merancang atau merumuskan konstitusi tersebut. Sedangkan original meaning theory menyatakan bahwa dalam mencari makna teks konstitusi harus didasarkan pada suasana saat teks tersebut dirumuskan. Hal ini bukan berarti bahwa penafsir mencoba masuk ke alam pikiran seseorang, akan tetapi berdasarkan kata yang diucapkan seseorang yang didasarkan pada makna kata saat kata tersebut digunakan. Dengan demikian, hal ini menekankan pada bagaimana teks tersebut dipahami oleh seseorang berdasarkan makna dalam sejarah konstitusi itu dirumuskan atau dilaksanakan untuk pertama kalinya. ${ }^{10}$

Sifat putusan MK pertama kali diatur di dalam UUD 1945 setelah perubahan ketiga, tepatnya Pasal 24C ayat (1) yang menyatakan "Mahkamah Konstitusi berwenang mengadili pada tingkat pertama dan terakhir yang putusannya bersifat final...". Pembahasan mengenai makna dari sifat putusan MK pada proses

9 Fajar Laksono Soeroso, “Aspek Keadilan Dalam Sifat Final Putusan Mahkamah Konstitusi” Jurnal Konstitusi, Volume 11, Nomor 1, Maret 2014, hlm 70

${ }^{10}$ Ibid., hlm. 71-72 
perubahan UUD 1945 ini tidak dibahas secara mendetail, bahkan dapat dikatakan sangat jarang sekali dibahas apalagi diperdebatkan.

Valina Singka Subekti menyatakan, mengenai kewenangan Mahkamah Konstitusi pada proses perumusan Mahkamah Konstitusi di Indonesia, bahwa penyelesaian perkara di lingkungan Mahkamah Konstitusi harus dilakukan dalam waktu yang cepat, dan tidak sepenuhnya perkara di Mahkamah Konstitusi dapat dijangkau oleh lingkungan peradilan umum. Atas dasar ini, putusan Mahkamah Konstitusi harus diletakkan sebagai putusan tingkat pertama dan terakhir. ${ }^{11} \mathrm{Hal}$ ini bahkan menurut Pattaniari Siahaan mempunyai korelasi dengan jumlah hakim konstitusi. Bahwa formulasi hakim konstitusi berjumlah 9 orang dimaksudkan agar persidangan bisa singkat cepat tetapi representatif, mengingat sidang Mahkamah Konstitusi merupakan pertama dan terakhir. ${ }^{12}$

Hamdan Zoelva menegaskan, bahwa pembentukan lembaga baru berupa Mahkamah Konstitusi telah menjadi kesepakatan bersama seiring dengan perubahan UUD 1945. Kewenangan yang menjadi kesepakatan seluruh pihak adalah untuk melindungi kemurnian konstitusi dengan memberikan tafsir secara lebih mendetail. Tafsir tersebut akan digunakan sebagai landasan untuk menyelesaikan persoalan-persoalan oleh otoritas tertentu yang diberikan langsung kewenangannya oleh Konstitusi. Berangkat dari hal tersebut, maka sudah selayaknya tafsir hanya dilakukan satu kali, yang berlaku secara mengikat. ${ }^{13}$

Tidak ada perdebatan secara detail mengenai sifat putusan Mahkamah Konstitusi dalam proses perumusan amendemen ketiga UUD 1945. Dapat dikatakan bahwa seluruh pihak yang terlibat, sejak awal hingga akhir pembahasan telah menyepakati ketentuan tersebut. Karenanya, rumusan akhir yang disepakati yaitu bahwa putusan Mahkamah Konstitusi merupakan putusan tingkat pertama dan terakhir yang bersifat final. ${ }^{14}$

11 Tim Penyusun Naskah Komprehensif Proses dan Hasil Perubahan UUD 1945, Naskah Komprehensif Perubahan Undang-Undang Dasar Negara Republik Indonesia: Buku VI, Kekuasaan Kehakiman, Edisi Revisi, Sekretariat Jenderal dan Kepaniteraan Mahkamah Konstitusi, Jakarta, 2010, hlm. 472

12 Ibid., hlm. 534

${ }^{13}$ Ibid., hlm. 484

${ }^{14}$ Ibid., hlm. 595 
Amanat UUD 1945 tersebut kemudian diderivasi ke dalam Undang-Undang Nomor 24 Tahun 2003 tentang Mahkamah Konstitusi. Pasal 10 ayat (1) mengatakan “Mahkamah Konstitusi berwenang mengadili pada tingkat pertama dan terakhir yang putusannya bersifat final...". Dijelaskan makna final pada undang-undang ini, yaitu putusan Mahkamah Konstitusi langsung memperoleh kekuatan hukum tetap sejak diucapkan dan tidak ada upaya hukum yang dapat ditempuh. Ketentuan lebih lanjut untuk memperjelas mengenai kekuatan hukum putusan Mahkamah Konstitusi dapat dilihat pada Pasal 47 yang menyatakan "Putusan Mahkamah Konstitusi memperoleh kekuatan hukum tetap sejak selesai diucapkan dalam sidang pleno terbuka untuk umum". Ketentuan mengenai sifat putusan Mahkamah Konstitusi sebagai bentuk derivasi dari UUD 1945 juga dapat ditemui pada Pasal 29 ayat (1) Undang-Undang Nomor 48 Tahun 2009 tentang Kekuasaan Kehakiman (UU Nomor 48 Tahun 2009), yang menyatakan bahwa "Mahkamah Konstitusi berwenang mengadili pada tingkat pertama dan terakhir yang putusannya bersifat final...".

Merujuk pada landasan yuridis di atas, tidak ditemukan kata mengikat sebagai sifat putusan Mahkamah Konstitusi yang seharusnya dipadukan dengan sifat final. Baik menurut UUD 1945, UU Nomor 24 Tahun 2003, maupun UU Nomor 48 Tahun 2009, hanya menegaskan bahwa putusan Mahkamah Konstitusi bersifat final. Menurut Syahrizal, hal tersebut merupakan kesalahan fatal yang dibuat oleh Majelis Permusyawaratan Rakyat dalam merumuskan amendemen UUD 1945. Syahrizal berpendapat bahwa artikulasi putusan final adalah tidak dapat dibanding, sehingga menimbulkan konsekuensi bahwa putusan tersebut secara normatif harus mengikat. Secara sederhana, putusan yang bersifat final harus juga diikuti dengan kata mengikat. Artikulasi normatif putusan final sekaligus mengikat (final and binding) sekalipun sudah dicantumkan secara tegas dalam konstitusi maupun landasan yuridis lainnya yang mengatur mengenai Mahkamah Konstitusi, sering kali juga menemukan kendala berupa tidak ditindaklanjuti oleh addressat putusan, apalagi jika tidak mencantumkannya. ${ }^{15}$

${ }^{15}$ Ahmad Syahrizal, Problem... Op., Cit., hlm. 115 
Pendapat yang serupa juga dinyatakan oleh Dahlan Thaib, bahwa dari aspek hukum ketatanegaraan, permasalahan yang muncul pasca amendemen UUD 1945, terutama yang berkaitan dengan Mahkamah Konstitusi adalah tidak menyebutkan secara eksplisit apakah putusan Mahkamah Konstitusi bersifat mengikat atau tidak. ${ }^{16}$ Menurut Dahlan Thaib, seharusnya setiap putusan yang final harus juga mengikat dan tidak dapat diulang kembali. Tidak menyebutkan dengan jelas klausul mengikat dalam sebuah putusan yang final, pada akhirnya akan mengakibatkan putusan Mahkamah Konstitusi mengambang. ${ }^{17}$

Pandangan berbeda disampaikan oleh Maruarar Siahaan, yang menyatakan bahwa pendapat tidak memasukkan klausul mengikat yang dipadukan dengan klausul final sehingga mengurangi kekuatan mengikatnya adalah pendapat yang kurang tepat. Pandangan tersebut mendasarkan pada Pasal 47 UU Nomor 24 Tahun 2003, bahwa putusan tingkat pertama dan terakhir yang final tersebut memperoleh kekuatan hukum tetap sejak diucapkan dalam sidang terbuka untuk umum yang bersifat erga omnes, yaitu sebuah putusan yang akibat hukumnya mengikat semua pihak.18 Fajar Laksono Soeroso berpendapat, bahwa makna makna mengikat telah tersirat dalam putusan yang bersifat final. Terlebih dalam peraturan perundang-undangan tersebut telah ditegaskan bahwa putusan Mahkamah Konstitusi merupakan tingkat pertama dan terakhir, yang berarti tidak ada upaya hukum lebih lanjut yang dapat ditempuh. Dengan demikian, putusan tersebut secara langsung mempunyai kekuatan hukum tetap dan memperoleh kekuatan hukum mengikat untuk dilaksanakan. ${ }^{19}$

Pada perkembangannya, kata mengikat kemudian muncul pada UndangUndang Nomor 8 Tahun 2011 tentang Perubahan Atas Undang-Undang Nomor 24 Tahun 2003 tentang Mahkamah Konstitusi yang merubah penjelasan Pasal 10 ayat (1) sehingga berbunyi “Putusan Mahkamah Konstitusi bersifat final, yakni putusan Mahkamah Konstitusi langsung memperoleh kekuatan hukum tetap sejak

\footnotetext{
${ }^{16}$ Dahlan Thaib, Ketatanegaan Indonesia Perspektif Konstitusional, Cetakan Pertama, Total Media, Yogyakarta, 2009, hlm. 255

${ }^{17}$ Ibid... hlm, 256

${ }_{18}$ Maruarar Siahaan, "Peran Mahkamah Konstitusi Dalam Penegakan Hukum Konstitusi”, Jurnal Hukum Nomor 3, Volume, 16 juli 2009, hlm. 359

19 Fajar Laksono, dkk., "Implikasi dan Implementasi Putusan Mahkamah Konstitusi Nomor 5/PUUX/2012 tentang SBI atau RSBI”, Jurnal Konstitusi, Volume 10, Nomor 4, Desember 2013, hlm. 739
} 
diucapkan dan tidak ada upaya hukum yang dapat ditempuh. Sifat final dalam putusan Mahkamah Konstitusi dalam Undang-Undang ini mencakup pula kekuatan hukum mengikat (final and binding)".

Berangkat dari beberapa penjelasan di atas, penulis berpendapat bahwa klausul mengikat memang penting untuk disebutkan secara eksplisit, termasuk di dalam UUD 1945 sebagai hukum tertinggi, dengan beberapa alasan. Pertama, putusan Mahkamah Konstitusi menduduki peranan yang sangat signifikan. Bagaimanapun upaya yang dilakukan oleh Mahkamah Konstitusi untuk menjaga kemurnian konstitusi guna melindungi hak konstitusional warga negara, dengan cara menafsirkannya, jika tidak diikuti kekuatan mengikat tentu hanya akan menjadi macan kertas dengan kekuatan simbolik yang hanya menghiasi berita negara. Menegaskan di dalam konstitusi bahwa putusan Mahkamah Konstitusi juga mengikat, di samping bersifat final, akan menjadikan sifat putusan tersebut lebih kokoh. Hal ini berangkat dari pemahaman bahwa konstitusi merupakan produk hukum yang tidak dapat diubah atau diganti dengan mudah. Kedua, tanpa menafikan bahwa makna final juga sudah mengandung arti mengikat secara implisit, namun demi kepastian hukum, kata mengikat juga penting untuk dicantumkan. Mengutip yang dikatakan oleh Satjipto Rahardjo bahwa kepastian hukum tidak turun dari langit. Kepastian hukum tidak jatuh bersamaan lahirnya undang-undang beserta pasal-pasal dan prosedurnya. Kepastian hukum membutuhkan pengerahan tenaga dan kekuatan. ${ }^{20}$

Ketentuan sifat final dan mengikat putusan Mahkamah Konstitusi ini juga diperkuat dengan adanya Putusan Nomor 129/PUU-VII/2009 dan Putusan Nomor 36/PUU-IX/2011. Putusan Nomor 129/PUU-VII/2009 menguji Pasal 10 ayat (1) UU Nomor 23 Tahun 2004. Putusan tersebut menunjukkan bahwa Mahkamah Konstitusi menyatakan permohonan para pemohon tidak dapat diterima. Demikian pula pada Putusan Nomor 36/PUU-IX/2011 yang juga menguji Pasal 10 ayat (1) huruf a Undang-Undang Nomor 24 Tahun 2003 tentang Mahkamah Konstitusi karena dinilai bertentangan dengan Pasal 28I ayat (2) UUD 1945. Salah satu dalil pemohon, bahwa dengan adanya ketentuan pasal tersebut maka

${ }^{20}$ Satjipto Rahardjo, Kepastian Hukum dan Kekuatan Bangsa, dalam Ahmad Syahrizal, Problem... Op. Cit., hlm. 
pemohon tidak dapat mengajukan upaya hukum dalam bentuk apapun terhadap putusan Mahkamah Konstitusi. Pada akhirnya, amar putusan Mahkamah Konstitusi juga menyatakan bahwa permohonan pemohon tidak dapat diterima.

Adanya putusan MK tersebut semakin menguatkan ketentuan final dan mengikat putusannya. Berkaitan dengan ini, Maruarar Siahaan berpendapat bahwa penyempurnaan hukum acara MK, termasuk dalam hal ini adalah putusan sebagai muara akhir dari proses beracara, adalah melalui peraturan MK maupun dengan yurisprudensi konstitusi. Hal ini juga mendasari dengan praktek di negaranegara lain seperti Korea. Pembuat undang-undang di Korea bahkan sangat menyadari kekurangan hukum acara yang diatur di dalam undang-undang Mahkamah Konstitusi Korea tersebut. ${ }^{21}$ Oleh karena itu, adanya putusan MK sebagaimana dijelaskan di atas yang memutuskan persoalan sifat final dan mengikat putusannya, telah menunjukkan secara tegas, bahwa produk hukum yang dikeluarkan oleh MK jelas tidak dapat ditawar kembali sifat final dan mengikatnya.

Beberapa penjelasan di atas menunjukkan bahwa sejak awal wacana dibentuknya MK di Indonesia hingga saat ini, sifat putusan dari institusi ini adalah final dan mengikat. Putusan final berarti bahwa putusan MK merupakan upaya yang pertama (the first resort) sekaligus upaya terakhir (the last resort) bagi para pencari keadilan. ${ }^{22}$ Ukuran untuk menentukan apakah putusan peradilan bersifat final atau tidak, dapat dilihat dari ada atau tidaknya badan atau institusi yang berwenang secara hukum untuk melakukan peninjauan ulang (review) terhadap putusan pengadilan tersebut, serta ada atau tidaknya prosedur atau mekanisme dalam hukum acara tentang siapa dan bagaimana cara peninjauan ulang tersebut dilakukan. ${ }^{23}$

Sifat final putusan MK ini menunjukkan setidaknya 3 hal mendasar, yaitu:24 Pertama, putusan MK secara langsung memperoleh kekuatan hukum. Kedua, putusan MK merupakan tingkat pertama dan terakhir, sehingga tidak ada upaya

${ }^{21}$ Maruarar Siahaan, Hukum Acara Mabkamah Konstitusi Republik Indonesia, Cetakan Pertama, Konstitusi Press, Jakarta, 2005, hlm. 4

${ }^{22}$ Bambang Sutiyoso, Hukum Acara Mabkamah Konstitusi Republik Indonesia, Cetakan Pertama, PT. Citra Aditya Bakti, Bandung, 2006, hlm. 160

${ }^{23}$ Maruarar Siahaan, Hukum..., Op. Cit., hlm. 275

${ }^{24}$ Fajar Laksono Soeroso, Aspek..., Op. Cit., hlm. 65 
hukum lain yang dapat ditempuh, seperti halnya banding ataupun kasasi pada peradilan umum. Putusan yang tidak dapat dilakukan upaya hukum lebih lanjut berarti telah mempunyai kekuatan hukum tetap dan secara langsung memperoleh kekuatan mengikat. Tidak adanya upaya hukum lebih lanjut ini sengaja dibuat dengan maksud agar Mahkamah Konstitusi melalui putusannya dapat menyelesaikan persoalan dan memberikan kepastian hukum secara cepat sesuai dengan prinsip peradilan cepat dan sederhana. Hal ini mengingat perkara yang diajukan kepada Mahkamah Konstitusi merupakan perkara yang berkaitan dengan ketatanegaraan, sehingga membutuhkan kepastian hukum dan terikat dengan limitasi waktu agar tidak mengganggu keberlangsungan agenda ketatanegaraan. ${ }^{25}$ Ketiga, karena telah memperoleh kekuatan hukum, maka putusan Mahkamah Konstitusi memiliki akibat hukum bagi semua pihak yang berkaitan dengan putusan. Pada konteks yang ketiga inilah putusan Mahkamah Konstitusi berbeda dengan putusan pengadilan biasa, tidak hanya meliputi pihak-pihak yang berperkara yaitu pemohon, pemerintah, Dewan Perwakilan Rakyat (DPR)/Dewan Perwakilan Daerah (DPD) ataupun pihak terkait yang diizinkan masuk ke dalam proses perkara, namun juga mengikat bagi semua pihak dan semua orang, lembaga-lembaga negara, serta badan-badan hukum yang berada dalam yurisdiksi wilayah Negara Kesatuan Republik Indonesia. Karena itu, putusan Mahkamah Konstitusi dikatakan bersifat erga omnes, yang ditujukan kepada semua orang. ${ }^{26}$ Perbedaan sifat mengikat Mahkamah Konstitusi yang berlaku kepada seluruh pihak ini dikarenakan sifat norma dalam bentuk undang-undang yang diuji dan norma yang dijadikan dasar pengujian yaitu konstitusi, adalah norma yang bersifat umum (abstract and impersonal). ${ }^{27}$

Menurut Fajar Laksono, landasan yang mendasari putusan Mahkamah Konstitusi merupakan putusan pada tingkat pertama sekaligus tingkat terakhir ini setidaknya dapat dilihat dari 2 alasan mendasar. Pertama, putusan Mahkamah Konstitusi bersifat final bukan hanya semata-mata bahwa Mahkamah Konstitusi

${ }^{25}$ Ibid., hlm. 78

${ }^{26}$ Maruarar Siahaan, Hukum..., Op. Cit., hlm. 208-209

27 Theodoron B. V. Runtuwene, "Kajian Yuridis Atas Putusan Mahkamah Konstitusi Nomor 34/PuuXi/2013 Dan Surat Edaran Mahkamah Agung Nomor 7 Tahun 2014 Ditinjau Dari Keadilan Dan Kepastian Hukum Terhadap Peninjauan Kembali", Lex Administratum, Vol. 3, Nomor 4 Juni 2015, hlm. 8 
merupakan satu-satunya lembaga peradilan yang menjalankan kewenangannya, dalam artian bahwa tidak ada lembaga lain atau bahkan lembaga peradilan yang lebih tinggi yang juga mempunyai kewenangan serupa dengan Mahkamah Konstitusi, namun lebih dari itu, putusan Mahkamah Konstitusi dilekatkan pada hakikat kedudukan konstitusi sebagai hukum tertinggi sehingga tidak ada hukum lain yang kedudukannya lebih tinggi dari pada itu. Hal ini disebabkan karena perkara yang dihadapkan pada Mahkamah Konstitusi untuk diselesaikan, dan menjadikan konstitusi sebagai batu uji atau dasar pengujiannya, maka hasil akhir atau putusan dari perkara tersebut mutlak bersifat final, karena tidak dimungkinkan lagi untuk dilakukan upaya lebih lanjut, serta batu uji yang lebih tinggi selain konstitusi. ${ }^{28}$ Artinya, putusan Mahkamah Konstitusi yang bersifat final merupakan konsekuensi logis dari sebuah negara hukum yang meletakkan konstitusi sebagai hukum tertingginya. Kedua, putusan Mahkamah Konstitusi yang bersifat final merupakan upaya untuk menjaga dan melindungi wibawa peradilan konstitusional. Alasan mendasar pada pendapat ini yaitu, jika peradilan konstitusi mengakomodasi adanya upaya hukum, maka tentu tidak ada bedanya dengan peradilan umum, yang biasanya sebuah perkara diajukan upaya hukum terhadap putusannya akan memakan waktu yang sangat panjang. Akibatnya adalah, para pihak akan mengalami ketersanderaan, baik waktu, tenaga, maupun biaya, yang kesemuanya bertentangan dengan asas peradilan yang diselenggarakan secara cepat, sederhana, dan biaya ringan. ${ }^{29}$ Jenedjri M. Gaffar berpendapat, bahwa putusan yang adil pun akan kehilangan makna apabila diputus dalam waktu yang lama dan tidak dapat segera diakses oleh masyarakat yang berhak (justice delayed, justice denied). ${ }^{30}$

Moh. Mahfud MD berpendapat, bahwa putusan Mahkamah Konstitusi memang harus tetap bersifat final. Setidaknya terdapat 3 alasan yang mendasari yaitu, pilihan vonis tergantung pada perspektif dan teori yang dipakai hakim; hukmul haakim yarfa'ul khilaf, yang artinya adalah putusan hakim menyelesaikan perbedaan; serta tidak ada alternatif yang lebih baik untuk menghilangkan sifat final. ${ }^{31}$

\footnotetext{
${ }^{28}$ Fajar Laksono, Aspek..., Op. Cit., hlm. 81

${ }^{29}$ Ibid.

${ }^{30}$ Janedjri M. Gaffar, "MK: Menegaskan Keadilan Substantif” Seputar Indonesia, 13 Agustus 2009.

31 Fajar Laksono, Aspek..., Op. Cit., hlm. 82
} 


\section{Sebab-sebab Putusan MK Tidak Dilaksanakan}

UU MK telah menegaskan bahwa putusan MK bersifat final dan mengikat sejak diucapkan dalam sidang pleno yang terbuka untuk umum. Faktanya, ternyata putusan MK tidak dapat dilaksanakan serta merta sejak setelah diucapkan dalam sidang pleno yang terbuka untuk umum. Penjelasan di dalam latar belakang telah menguraikan bukti konkret mengenai hal tersebut. Berdasarkan hasil analisis beberapa putusan di atas, peneliti mengikhtisarkan beberapa faktor sebagai berikut:

\section{Mahkamah Konstitusi sebagai Negative Legislature}

Sejak awal pembentukannya, MK hanya diberikan tugas konstitusional untuk mereview produk legislatif dengan batu uji konstitusi sebagai hukum tertinggi. ${ }^{32}$ MK berwenang untuk membatalkan undang-undang atau menyatakan undangundang tidak mengikat secara hukum, sebagai kontrol eksternal dalam proses legislasi. ${ }^{33}$ Kewenangan terbatas dan lemah MK ini tentu berpengaruh terhadap tindaklanjut putusannya. Alexander Hamilton dalam Federalist Paper bahkan telah menegaskan bahwa MK merupakan cabang kekuasaan paling lemah di antara cabang kekuasaan lainnya.

The judiciary, from the nature of its function, will always be least dangerous of the political rights of the constitution. The executive holds the sword of the community and the legislature the purse: the judiciary, on the contrary has no influence over either the sword or the purse; no direction either of the strength of the wealth of society, and take no active resolution whatever. The court may truly be said to have neither force no will but merely judgment; and must ultimately depend upon the aid of executive arm for the efficacious exercise even this facility. The judiciary is therefore the weakest of the three branchess. ${ }^{34}$

Robert Dahl juga mengatakan hal yang serupa.

The Court is almost powerless to affect the course of national policy. This is because the court's rulings are not self-executing. Enforcement and implementation require the cooperation and coordination of all branches of government. 35

\footnotetext{
${ }^{32}$ Mukti Fadjar, "MK Sebagai Negative Legislator” dalam https:/ / prasetya.ub.ac.id/berita/Prof-Dr-MuktiFadjar-MK-Sebagai-Negative-Legislator-821-id.pdf, diakses pada tanggal 2 Agustus 2017

33 Saldi Isra, "Negative Legislator" dalam https://www.saldiisra.web.id/index.php/21makalah/makalah1/302-negative-legislator.html, diakses pada tanggal 2 Agustus 2017

34 Alexander Hamilton, The Federalist Papers, dalam Inosentius Samsul, Laporan Akhir Pengkajian Hukum Tentang Putusan Mabkamah Konstitusi, Badan Pembinaan Hukum Nasional, Kementerian Hukum dan HAM RI, 2009, hlm. 3

35 Jamaludin Ghofur, "Membangun Sinergitas Mahkamah Konstitusi dengan Lembaga Legislatif dan Eksekutif (Upaya Memaksimalkan Implementasi Putusan Mahkamah Konstitusi)” Jurnal Konstitusi, Volume II, November 2009, hlm. 52
} 
Pendapat tokoh tersebut menunjukkan bahwa MK memang menjadi institusi paling lemah dibandingkan dengan yang lain. Bahkan, lemahnya MK tersebut memang dapat dibuktikan secara konstitusional, bahwa dalam keadaan maksimal, hanya dapat menghapus dan membatalkan norma saja. ${ }^{36}$

Secara umum, sifat putusan pengadilan dapat dikualifikasikan ke dalam tiga jenis, yaitu declaratoir, constitutief, dan condemnatoir. Putusan dikatakan condemnatoir apabila putusan tersebut berisi suatu penghukuman bagi tergugat atau termohon untuk melakukan suatu prestasi. Putusan declaratoir yaitu putusan yang menyatakan apa yang menjadi hukum, atau menegaskan suatu keadaan hukum. Sedangkan putusan constitutief berarti bahwa putusan yang meniadakan suatu keadaan hukum, atau menimbulkan suatu keadaan hukum yang baru. ${ }^{37}$ Berdasarkan kerangka tersebut, putusan MK dapat dikualifikasikan ke dalam putusan declaratoir dan constitutief. Pasal 56 ayat (3) Undang-Undang Mahkamah Konstitusi merupakan pijakan dari pendapat tersebut, bahwa Mahkamah Konstitusi menyatakan secara tegas materi muatan suatu undang-undang, pasal, dan/atau ayat bertentangan dengan UUD. Putusan yang demikian juga secara otomatis akan memenuhi kualifikasi sifat constitutief, karena menyatakan suatu undang-undang bertentangan dengan UUD 1945, juga akan melahirkan keadaan hukum baru, yaitu kekuatan mengikat suatu undang-undang tersebut akan hilang. ${ }^{38}$ Namun demikian, putusan yang membutuhkan tindaklanjut, MK tidak dapat menindaklanjuti putusannya. Selebihnya tergantung pada lembaga yang bersangkutan apakah putusan tersebut akan diimplementasikan atau tidak. Ketiga contoh konkret putusan di atas menggantungkan tindaklanjut cabang kekuasaan lain untuk diimplementasikan, dan MK tidak mempunyai kekuasaan melebihi kapasitasnya sebagai negatif legislator.

Ketiga contoh putusan di atas kiranya tepat sekali dijadikan bukti konkret. Salah satu yang sangat tampak adalah Putusan Nomor 34/PUU-XI/2013 yang

\footnotetext{
36 Moh. Mahfud MD, "Rambu Pembatas dan Perluasan Kewenangan Mahkamah Konstitusi", Jurnal Hukum, Nomor 4, Volume 16, Oktober 2009, hlm. 453

${ }^{37}$ Retnowulan Sutantio dan Iskandar Oeripkartawinata, Hukumm Acara Perdata dalam Teori dan Praktek, Cetakan Kesebelas, Mandar Maju, Bandung, 2009, hlm. 109

38 Abdul Latif, Fungsi Mabkamah Konstitusi Dalam Upaya Mewnjudkan Negara Hukum Demokrasi, Cetakan Pertama, Kreasi Total Media, Yogyakarta, 2007, hlm. 211
} 
mempunyai konsekuensi yuridis berupa Peninjauan Kembali yang boleh dilakukan lebih dari sekali. Pasca putusan tersebut dikeluarkan, MA justru mengeluarkan Surat Edaran Mahkamah Agung (SEMA) Nomor 07 Tahun 2014 tentang Pengajuan Permohonan Peninjauan Kembali Dalam Perkara Pidana, yang secara substansial menegaskan bahwa Peninjauan Kembali hanya boleh dilakukan sekali. Secara formal, SEMA tersebut memang merujuk pada Undang-Undang di luar yang diujikan dan dibatalkan $\mathrm{MK}$, namun secara substansial, hal itu merupakan bentuk "penentangan" MA terhadap putusan MK. Dalam keadaan demikian, MK tidak dapat bertindak apapun karena kewenangannya telah selesai sejak memutuskan bahwa pasal yang bersangkutan inkonstitusional. Keberadaannya hanya sebatas sebagai negatif legislator yang tidak mampu membentuk norma baru sebagai tindaklanjut dari putusannya.

\section{Tidak Adanya Special Enforcement Agencies}

Dibandingkan dengan insititusi peradilan lainnya, MK merupakan institusi peradilan yang tidak mempunyai unit eksekutorial seperti juru sita atau kepolisian. Pada awal pembentukannya, MK memang akan menentukan konstitusionalitas undang-undang. Akibatnya, sejalan dengan pendapat Bambang Sutiyoso bahwa suatu undang-undang yang dinyatakan inkonstitusional, dengan sendirinya tidak mempunyai kekuatan mengikat dan tidak dapat dijadikan dasar hukum. ${ }^{39}$ Pada perkembangannya, putusan MK tidak hanya berhenti pada dinyatakannya inkonstitusional putusan tersebut dalam persidangan, namun membutuhkan tindaklanjut tertentu. Putusan MK hanya akan menjadi macan kertas, formalitas, dan tidak mempunyai arti apa-apa ketika cabang kekuasaan lain justru mengadopsi kembali ketentuan yang dibatalkan dan bertindak berdasarkan kewenangannya yang bertentangan dengan putusan MK. Pada saat yang bersamaan, MK tidak memiliki unit eksekutorial untuk memaksakan pihak lain mematuhi dan melaksanakan putusannya.

Berdasarkan penjelasan di atas, implementasi putusan MK sangat bergantung pada cabang kekuasaan lainnya untuk menindaklanjuti putusan tersebut. Hal ini sejalan dengan pendapat Maruarar Siahaan, bahwa putusan MK sangat sering 
sekali memperhadapkan MK dengan cabang kekuasaan negara lainnya, baik eksekutif, legislatif, maupun institusi lain. Hal ini memang sebuah kewajaran mengingat tindaklanjut putusan MK mayoritas membutuhkan instrumen hukum lainnya, di mana hal tersebut menjadi domain institusi lain. ${ }^{40}$ Faktanya, beberapa putusan di atas yang dijadikan obyek penelitian ini, tidak dilaksanakan secara konsekuen sesuai dengan amanah undang-undang oleh cabang kekuasan lain sebagai addressat putusan, bahkan menimbulkan pertentangan, namun MK tidak dapat bertindak apapun atas fakta tersebut. MK juga tidak mampu menggerakkan institusi lain untuk memaksakan hal tersebut.

\section{Tidak Adanya Tenggang Waktu Implementasi Putusan}

Fakta yuridis kiranya cukup memberikan kontribusi atas tidak terimplementasikannya putusan MK secara konsekuen. UU MK menegaskan secara eksplisit bahwa putusan MK berlaku final dan mengikat sejak diucapkan dalam sidang pleno yang terbuka untuk umum. Konsekuensi yuridis atas ketentuan ini yaitu putusan MK sudah harus dilaksanakan sejak diucapkan sesuai dengan bunyi amar putusannya. Keadaan yang demikian kiranya juga akan mempersulit addressat putusan untuk mengimplementasikan putusan Mahkamah Konstitusi. Harus diakui bahwa putusan Mahkamah Konstitusi tidak serta merta dapat diimplementasikan seketika itu juga, namun membutuhkan proses dan masa transisi. Hal ini terutama yang berkaitan dengan lembaga legislatif sehingga membutuhkan instrumen hukum baru dalam bentuk revisi atau undang-undang baru, padahal pembentukan undang-undang berkarakter formal prosedural. ${ }^{41}$

Putusan MK yang tidak dapat dilaksanakan serta merta, juga berkaitan dengan kekacauan politik. Dalam keadaan tertentu, sangat dimungkinkan putusan Mahkamah Konstitusi yang secara langsung mengubah ketentuan dalam undangundang, akan menimbulkan ketidakjelasan politik. Hal ini berkaitan dengan undang-undang yang memang secara mutlak harus berlaku. Sebagai contohnya yaitu Undang-Undang tentang Anggaran Pendapatan dan Belanja Negara. Merubah secara signifikan ketentuan dalam undang-undang tersebut tentu sangat

\footnotetext{
${ }^{40}$ Maruarar Siahaan, Hukum..., Op. Cit., hlm. 357

${ }^{41}$ Nurrahman Aji Utomo, "Dinamika Hubungan Antara Pengujian Undang-Undang dengan Pembentukan Undang-Undang”, Jurnal Konstitusi, Volume 12, Nomor 4 Desember 2015, hlm. 842
} 
potensial sekali menimbulkan kekacauan. Dalam hal ini, memang diperlukan tahapan-tahapan tertentu untuk mengimplementasikan putusan Mahkamah Konstitusi.

Merujuk pada beberap putusan MK di atas, ada setidaknya 2 putusan yang sangat berkaitan erat dengan hal ini. Pertama, Putusan Nomor 5/PUU-X/2012 yang mempunyai akibat hukum bahwa Rintisan Sekolah Bertaraf Internasional/Sekolah Bertaraf Internasional (RSBI/SBI) adalah inkonstitusional. Putusan ini membutuhkan tindaklanjut dari pemerintah, dalam hal ini adalah Menteri Pendidikan dan Kebudayaan untuk mencabut Surat Keputusan sekolah yang telah dimasukkan ke dalam kualifikasi RSBI/SBI. Pemerintah juga harus memerintahkan seluruh sekolah di Indonesia untuk mencabut seluruh atribut yang menunjukkan identitas RSBI/SBI. Hal ini tentu tidak dapat dilakukan dalam jangka waktu yang singkat. Memerlukan waktu yang cukup lama untuk melaksanakan putusan MK tersebut. Pada akhirnya, MK pun menyadari akan tenggang waktu itu, dengan memberikan masa transisi kepada Menteri Pendidikan untuk menjalankan putusan MK. Harus disadari, jika memang amanah undangundang telah menegaskan bahwa putusan MK berlaku final dan mengikat sejak diucapkan dalam sidang pleno yang terbuka untuk umum, maka kebijakan transisi seharusnya bertentangan dengan amanah undang-undang.

Kedua, Putusan Nomor 011/PUU-III/2005 yang menegaskan bahwa alokasi dana pendidikan harus diberikan 20\% secara langsung tanpa berangsur. Faktanya, hal itu tidak dapat dilakukan secara konsekuen oleh lembaga legislatif dalam menganggarkan dana pendidikan. Hal ini merupakan sebuah kewajaran mengingat anggaran dana pendidikan tersebut terdapat di dalam Undang-Undang tentang Anggaran Pendapatan dan Belanja Negara, yang apabila ketentuan undang-undang tersebut dirubah serta merta akan berdampak pada situasi politik. Namun jika dibenturkan dengan konsekuensi yuridis pelaksanaan putusan MK, tentu keadaan tersebut tidak dapat dibenarkan.

Kedua contoh di atas menunjukkan, dalam keadaan tertentu, putusan MK memang tidak dapat serta merta dilaksanakan sejak mempunyai kekuatan hukum mengikat, yaitu sejak diucapkan dalam sidang pleno yang terbuka untuk umum. 
Beberapa putusan harus melalui jangka waktu yang cukup panjang tergantung pada kondisi sosial, politik, dan ekonomi negara Indonesia.

\section{Tidak Adanya Konsekuensi Yuridis atas Pengabaian Putusan}

Normativisasi hukum memang tidak cukup hanya sebatas memuat perintah dan larangan. Keadaan tersebut sangat rentan sekali untuk dilanggar atau tidak dipatuhi. Oleh karena itu, dibalik perintah dan larangan, juga penting untuk mengadopsi ketentuan mengenai sanksi atas ketidakpatuhan. Hingga saat ini, sanksi hukum memang harus diakui merupakan alat yang paling ampuh untuk menjaga kewibawaan hukum, dalam hal ini adalah untuk menjaga kepatuhan terhadap substansi hukum. ${ }^{42}$ Hal inilah kiranya yang juga menjadi celah atas putusan Mahkamah Konstitusi yang tidak implementatif.

Hasil wawancara penulis kepada Badan Pengkajian Majelis Permusyawaratan Rakyat mengenai beberapa putusan Mahkamah Konstitusi yang tidak implementatif mengatakan, bahwa pengabaian terhadap putusan Mahkamah Konstitusi tidak mempunyai sanksi yang tegas. Perkara yang diajukan kepada Mahkamah Konstitusi seakan telah selesai ketika dikeluarkannya putusan Mahkamah Konstitusi. Baik pemohon yang telah mengajukan pengujian suatu undang-undang tertentu, maupun Mahkamah Konstitusi seakan tidak mempunyai kepentingan terhadap tindaklanjut putusan Mahkamah Konstitusi. Pada akhirnya, putusan Mahkamah Konstitusi yang tidak dilaksanakan, akan mengambang saja. ${ }^{43}$

Merujuk pada beberapa putusan Mahkamah Konstitusi di atas, tidak dilaksanakannya putusan Mahkamah Konstitusi, sama sekali tidak mempunyai konsekuensi tertentu. Baik Mahkamah Konstitusi sebagai institusi yang mengeluarkan putusan tersebut, maupun institusi-institusi lainnya, tidak mempunyai hak untuk masuk ke ranah tersebut. Mahkamah Konstitusi tidak dapat bertindak secara aktif untuk menyelesaikan suatu persoalan, bahkan apabila putusannya diabaikan. Pembatalan Undang-Undang tentang Sistem Pendidikan Nasional yang berkaitan dengan anggaran pendidikan tidak mencapai 20\%,

\footnotetext{
42 Bambang Sutiyoso, Tata Cara Penyelesaian Sengketa di Lingkungan Mabkamah Konstitusi, Cetakan Pertama, UII Press, Yogyakarta, 2009, hlm. 124

${ }^{43}$ Hasil wawancara penulis bersama Bambang Sadono, Ketua Bidang Pengkajian Majelis Permusyawaratan Rakyat Republik Indonesia, dilaksanakan pada tanggal 20 Juli 2017
} 
kemudian secara substansial diakomodir kembali melalui Undang-Undang APBN, ditanggapi oleh Ketua Mahkamah Konstitusi yang pada waktu itu adalah Jimly Asshiddiqie, dengan mempersilahkan setiap orang untuk mengajukan gugatan kepada Mahkamah Konstitusi.

\section{Penutup}

Berdasarkan analisis sebagaimana dijelaskan di atas, maka dalam penelitian ini dapat disimpulkan sebagai berikut. Pertama, putusan final berarti bahwa putusan Mahkamah Konstitusi merupakan upaya yang pertama (the first resort) sekaligus upaya terakhir (the last resort) bagi para pencari keadilan. Artikulasi putusan final berarti tidak ada upaya hukum lebih lanjut yang dapat ditempuh terhadap putusan, sehingga menimbulkan konsekuensi bahwa putusan tersebut secara langsung mempunyai kekuatan hukum tetap dan memperoleh kekuatan hukum mengikat untuk dilaksanakan. Putusan memperoleh kekuatan final dan mengikat sejak diucapkan di dalam pleno yang terbuka untuk umum. Putusan final Mahkamah Konstitusi dimaksudkan agar dapat menyelesaikan persoalan dan memberikan kepastian hukum secara cepat sesuai dengan prinsip peradilan cepat dan sederhana mengingat perkara yang diajukan kepada Mahkamah Konstitusi merupakan perkara yang berkaitan dengan ketatanegaraan, sehingga membutuhkan kepastian hukum dan terikat dengan limitasi waktu agar tidak mengganggu keberlangsungan agenda ketatanegaraan. Jika tidak, kewibawaan peradilan konstitusional yang harus dipertaruhkan. Pada aspek yang lebih luas, putusan yang adil pun akan kehilangan makna apabila diputus dalam waktu yang lama dan tidak dapat segera diakses oleh masyarakat yang berhak (justice delayed, justice denied). Selain itu, karakteristik utama putusan mengikat Mahkamah Konstitusi yaitu sifatnya yang erga omnes, yaitu sebuah putusan yang akibat hukumnya mengikat semua pihak. Hal ini dikarenakan sifat norma dalam bentuk undang-undang yang diuji dan norma yang dijadikan dasar pengujian yaitu konstitusi, adalah norma yang bersifat umum (abstract and impersonal).

Kedua, belum diimplementasikan secara konsekuen putusan MK karena beberapa faktor diantaranya adalah Mahkamah Konstitusi yang secara alamiah sebagai negative legislature; tidak adanya special enforcement agencies; tidak adanya 
tenggang waktu implementasi putusan; tidak adanya konsekuensi atas pengabaian terhadap putusan Mahkamah Konstitusi.

Mahkamah Konstitusi sebagai institusi peradilan sudah barang tentu meletakkan putusan sebagai mahkotanya. Putusan yang hanya menjadi macan kertas dan penghias lembaran negara tentu hanya akan menurunkan kewibawaan Mahkamah Konstitusi sebagai peradilan konstitusional. Oleh karena itu, guna menciptakan putusan final dan mengikat yang implementatif, tentu berangkat dari analisis dan kerangka konseptual sebagaimana dijelaskan di atas, maka penulis mencoba menyampaikan saran sebagai berikut: artikulasi putusan final putusan Mahkamah Konstitusi pada konstitusi tidak diikuti dengan klausul mengikat, karena dinilai telah mengandung makna tersebut secara implisit, padahal lumrahnya, klausul final selalu diikuti dengan kata mengikat (final and binding). Karena itu, tanpa menafikan makna implisit yang telah terkandung di dalamnya, klausul mengikat juga penting untuk dicantumkan secara eksplisit, sebagai ikhtiar menciptakan kepastian hukum, sekaligus meminimalisir kemungkinan putusan yang hanya akan menjadi macan kertas dengan kekuatan simbolik yang menghiasi berita negara.

\section{Daftar Pustaka}

\section{Buku}

Asshiddiqie, Jimly, Perkembangan \& Konsolidasi Lembaga Negara Pasca Reformasi, Edisi Kedua, Cetakan Kedua, Sinar Grafika, Jakarta, 2012.

Latif, Abdul, Fungsi Mahkamah Konstitusi Dalam Upaya Mewujudkan Negara Hukum Demokrasi, Cetakan Pertama, Kreasi Total Media, Yogyakarta, 2007.

Siahaan, Maruarar, Hukum Acara Mahkamah Konstitusi Republik Indonesia, Cetakan Pertama, Konstitusi Press, Jakarta, 2005.

,Undang-Undang Dasar 1945 Konstitusi Yang Hidup, Sekretariat Jenderal dan Kepaniteraan Mahkamah Konstitusi, Jakarta, 2008.

Soekanto, Soerjono, Pengantar Penelitian Hukum, Cetakan Ketiga, UI Press, Jakarta, 2015.

Soemitro, Ronny Hanitijo, Metodologi Penelitian Hukum dan Jurimetri, Cetakan Ketiga, Ghalia Indonesia, Jakarta, 1988.

Sutantio, Retnowulan dan Iskandar Oeripkartawinata, Hukumm Acara Perdata dalam Teori dan Praktek, Cetakan Kesebelas, Mandar Maju, Bandung, 2009. 
Sutiyoso, Bambang, Hukum Acara Mahkamah Konstitusi Republik Indonesia, Cetakan Pertama, PT. Citra Aditya Bakti, Bandung, 2006.

, Tata Cara Penyelesaian Sengketa di Lingkungan Mahkamah Konstitusi, Cetakan Pertama, UII Press, Yogyakarta, 2009.

Thaib, Dahlan, Ketatanegaan Indonesia Perspektif Konstitusional, Cetakan Pertama, Total Media, Yogyakarta, 2009.

Tim Penyusun Hukum Acara Mahkamah Konstitusi, Hukum Acara Mahkamah Konstitusi, Cetakan Pertama, Sekretariat Jenderal dan Kepaniteraan Mahkamah Konstitusi, Jakarta, 2010.

Tim Penyusun Naskah Komprehensif Proses dan Hasil Perubahan UUD 1945, Naskah Komprehensif Perubahan Undang-Undang Dasar Negara Republik Indonesia: Buku VI, Kekuasaan Kehakiman, Edisi Revisi, Sekretariat Jenderal dan Kepaniteraan Mahkamah Konstitusi, Jakarta, 2010.

\section{Jurnal dan Hasil Penelitian}

Ghofur, Jamaludin, “Membangun Sinergitas Mahkamah Konstitusi dengan Lembaga Legislatif dan Eksekutif (Upaya Memaksimalkan Implementasi Putusan Mahkamah Konstitusi)" Jurnal Konstitusi, Volume II, November 2009.

Laksono, Fajar, dkk, "Implementasi Putusan Mahkamah Konstitusi Nomor 92/PUU-X/2012 Terkait Kewenangan Dewan Perwakilan Daerah dalam Pembentukan Undang-Undang" Jurnal Konstitusi Volume 12, Nomor 3, September 2015.

"Implikasi dan Implementasi Putusan Mahkamah Konstitusi Nomor 5/PUU-X/2012 Tentang SBI atau RSBI", Jurnal Konstitusi, Volume 10, Nomor 4, Desember 2013.

Mahfud MD, Moh., "Peran Mahkamah Konstitusi dalam Pengembangan Hukum dan Demokrasi di Indonesia" dalam Mariyadi Faqih, "Nilai-Nilai Filosofi Putusan Mahkamah Konstitusi yang Final dan Mengikat", Jurnal Konstitusi, Volume 7, Nomor 3, Juni 2010.

, "Rambu Pembatas dan Perluasan Kewenangan Mahkamah Konstitusi", Jurnal Hukum, Nomor 4, Volume 16, Oktober 2009.

Runtuwene, Theodoron B. V., “Kajian Yuridis Atas Putusan Mahkamah Konstitusi Nomor 34/PUU-Xi/2013 Dan Surat Edaran Mahkamah Agung Nomor 7 Tahun 2014 Ditinjau Dari Keadilan Dan Kepastian Hukum Terhadap Peninjauan Kembali", Lex Administratum, Vol. 3, Nomor 4 Juni 2015.

Samsul, Inosentius, Laporan Akhir Pengkajian Hukum Tentang Putusan Mahkamah Konstitusi, Badan Pembinaan Hukum Nasional, Kementerian Hukum dan HAM RI, 2009.

Siahaan, Maruarar, "Peran Mahkamah Konstitusi Dalam Penegakan Hukum Konstitusi", Jurnal Hukum Nomor 3, Volume, 16 juli 2009. 
Soeroso, Fajar Laksono, “Aspek Keadilan Dalam Sifat Final Putusan Mahkamah Konstitusi" Jurnal Konstitusi, Volume 11, Nomor 1, Maret 2014.

Syahrizal, Ahmad, "Problem Implementasi Putusan MK" Jurnal Konstitusi, Volume 4, Nomor 1, Maret 2007.

Utomo, Nurrahman Aji, “Dinamika Hubungan Antara Pengujian Undang-Undang dengan Pembentukan Undang-Undang", Jurnal Konstitusi, Volume 12, Nomor 4 Desember 2015.

\section{Undang-Undang dan Putusan Pengadilan}

Undang-Undang Dasar Negara Republik Indonesia 1945.

Undang-Undang Nomor 8 Tahun 2011 tentang Perubahan Atas Undang-Undang Nomor 24 Tahun 2003 tentang Mahkamah Konstitusi (Tambahan Lembaran Negara Republik Indonesia Nomor 5226).

Putusan Mahkamah Konstitusi Nomor 011/PUU-III/2005.

Putusan Mahkamah Konstitusi Nomor 5/PUU-X/2012.

Putusan Mahkamah Konstitusi Nomor 34/PUU-XI/2013.

\section{Media}

Gaffar, Janedjri M., "MK: Menegaskan Keadilan Substantif” Seputar Indonesia, 13 Agustus 2009.

\section{Website}

Anonim, "APBN 2006, Pemerintah dan DPR Abaikan Putusan MK" dalam http:/ / www.hukumonline.com/berita/baca/hol13876/apbn-2006pemerintah-dan-dpr-abaikan-putusan-mk, diakses pada tanggal 05 Mei 2017.

Fadjar, Mukti, "MK Sebagai Negative Legislator" dalam https:/ / prasetya.ub.ac.id/berita/Prof-Dr-Mukti-Fadjar-MK-SebagaiNegative-Legislator-821-id.pdf, diakses pada tanggal 2 Agustus 2017

Isra, Saldi, "Negative Legislator" dalam https://www.saldiisra.web.id/ index.php/21-makalah/makalah1/302-negative-legislator.html, diakses pada tanggal 2 Agustus 2017 